This item was submitted to Loughborough's Research Repository by the author.

Items in Figshare are protected by copyright, with all rights reserved, unless otherwise indicated.

\title{
Stunting is not a synonym of malnutrition
}

PLEASE CITE THE PUBLISHED VERSION

https://doi.org/10.1038/s41430-019-0439-4

PUBLISHER

Springer

VERSION

AM (Accepted Manuscript)

PUBLISHER STATEMENT

This paper was accepted for publication in the journal European Journal of Clinical Nutrition and the definitive published version is available at https://doi.org/10.1038/s41430-019-0439-4

\section{LICENCE}

CC BY-NC-ND 4.0

\section{REPOSITORY RECORD}

Scheffler, C, M Hermanussen, Barry Bogin, DS Liana, F Taolin, PMVP Cempaka, M Irawan, et al.. 2020. "Stunting Is Not a Synonym of Malnutrition". Loughborough University. https://hdl.handle.net/2134/13237958.v1. 
1

2

3

4

5

6

7

8

9

Stunting is not a synonym of malnutrition.

Scheffler C1, Hermanussen M2, Bogin B3, Liana DS4, Taolin F5; Cempaka PMVP5, Irawan M5, Ibbibah LF5, Mappapa NK4, Payong MKE4, Homalessy AV4, Takalapeta A4, Apriyanti S4, Manoeroe MG4, Dupe FR4, Ratri RRK4, Touw SY4, K PV4, Murtani BJ4, Nunuhitu R4, Puspitasari R6, Riandra IK7, Liwan AS7, Amandari P7, Permatasari AAI7, Julia M8, Batubara J9,10, Pulungan A10,11

1 University of Potsdam, Human Biology, 14469 Potsdam, Germany; 2 Aschauhof, 24340 Altenhof, Germany;

3 Centre for Global Health \& Human Development, School of Sport, Exercise \& Health Sciences, Loughborough University, Leicestershire LE11 3TU, UK;

4 Medical Faculty Nusa Cendana University, Kupang-East Nusa Tenggara, Indonesia;

5 East Nusa Tenggara Indonesian Society of Pediatrician, Kupang-East Nusa Tenggara, Indonesia; 6 School of Medicine, University of Sumatera Utara, Medan, Sumatera Utara, Indonesia; 7 Regional General Hospital Wangaya Denpasar;

8 Department of Child Health, Faculty of Medicine, Public Health and Nursing, Universitas Gadjah Mada, Yogyakarta, Indonesia;

9 Department of Child Health, Medical School, University of Indonesia, Jakarta 10430. Indonesia; 10 Indonesian Pediatric Society 11 Department of Child Health University of Indonesia, Dr. Cipto Mangunkusumo Hospital, Jakarta 10430, Indonesia.

\section{Running title: Stunting is not a synonym of malnutrition}

\section{Authors emails:}

christiane.scheffler@uni-potsdam.de

michael.hermanussen@gmail.com

B.A.Bogin@lboro.ac.uk

rayadeboras|@gmail.com

franstaolin01@yahoo.com 
33 muhammadirawan86@gmail.com

34 laylaibbibah@yahoo.com

35 mnurmalinda@yahoo.com

36 esterpayong@gmail.com

37 alexandrohomalessy@gmail.com

38 anita.takalapeta@gmail.com

39 selvianaapriyanti@gmail.com

40 michelle.giovanny.mg@gmail.com

41 frenyrosadupe@gmail.com

42 theresiakenny@gmail.com

43 samytouw@gmail.com

44 priska_valinia@gmail.com

45 belindamurtani@yahoo.com

46 rendynunuhitu96@gmail.com

47 crystal.ria37@gmail.com

48 indahriandra@gmail.com

49 armandliwan@gmail.com

50 prabhaamandari@yahoo.com

51 aaindahpermatasari@gmail.com

52 madarinajulia@ugm.ac.id

53 josebatubara@gmail.com

54 amanpulungan@mac.com

55

56 Corresponding author:

57

58 Prof. Dr. Michael Hermanussen

59 Aschauhof 3

6024340 Eckernförde - Altenhof

61 Germany

$62 \quad 0049-(0) 4351-41738$ 
Mobile 0049-(0)174-6173023

michael.hermanussen@gmail.com

\section{Contributors' statement:}

Study design: Scheffler C, Hermanussen M, Bogin B

Literature search: Scheffler C, Hermanussen M, Bogin B

Measurements: Indonesia -- Scheffler C, Hermanussen M, and the Indonesian co-authors: Liana DS,

Fransiskus T; Cempaka PMVP, Irawan M, Ibbibah LF, Mappapa NK, Payong MKE, Homalessy AV,

Takalapeta A, Apriyanti S, Manoeroe MG, Dupe FR, Ratri RRK, Touw SY, K PV, Murtani BJ, Nunukitu

R, Puspitasari R, Riandra IK, Liwan AS, Amandari P, Permatasari AAI, equally contributed to the measurements of the children.

Local organization of the study: Julia M, Batubara J, Pulungan A

Data analysis: Scheffler C, Hermanussen M, Bogin B

Data interpretation: Scheffler C, Hermanussen M, Bogin B

Writing: Scheffler C, Hermanussen M, Bogin B

Figures: Bogin B, Scheffler C

(1)

\section{Role of the funding source}

There was no funding for data collection, analysis, or interpretation of the data; there was no funding for trial design; subject recruitment; there was partial funding of travel expenses by the Indonesian Pediatric Society, managed by Pulungan A.

The corresponding author Michael Hermanussen has full access to all the data in the study and had final responsibility for the decision to submit for publication

\section{Key words:}

Energy balance, malnutrition, stunting, skinfold thickness, Indonesia 
96 Abbreviations:

97 BMI body mass index

$98 \mathrm{FI} \quad$ Frame Index (elbow breadth/height)

99 GDP gross domestic product

100 hSDS height standard deviation score

101 LMIC low and middle-income countries

102 MUAC mid upper arm circumference

103 PEM protein-energy malnutrition

104 SD standard deviation

105 SES socioeconomic status

106 WHO World Health Organisation

$107 \overline{\mathrm{X} S F}$ mean of triceps and subscapular skinfolds

108

109 
Abstract

112

\section{Background}

WHO documents characterize stunting as, “...impaired growth and development that children experience from poor nutrition, repeated infection, and inadequate psychosocial stimulation." The equation of stunting with malnutrition is common. This contrasts with historic and modern observations indicating that growth in height is largely independent of the extent and nature of the diet.

\section{Subjects}

We measured 1716 Indonesian children, aged 6.0-13.2 years, from urban Kupang/West-Timor and rural Soe/West-Timor, urban Ubud/Bali, and rural Marbau/North Sumatra. We clinically assessed signs of malnutrition and skin infections.

\section{Results}

There was no relevant correlation between nutritional status (indicated by skinfold thickness) and height SDS (hSDS). $53 \%$ of boys, and $46 \%$ girls in rural Soe were short and thin, with no meaningful association between mean of triceps and subscapular skinfolds ( $\bar{x} S F)$ and height. Skinfold thickness was close to German values. Shortest and tallest children did not differ relevantly in skinfold thickness. The same applied for the association between hSDS and mid upper arm circumference (MUAC) using linear mixed effects models with both fixed and random effects. $35.6 \%$ boys and $29.2 \%$ girls in urban Ubud were overweight; $21.4 \%$ boys and $12.4 \%$ girls obese, but with hSDS $=-0.3$, still short. Relevant associations between $\mathrm{hSDS}$ and $\overline{\mathrm{x}} \mathrm{SF}$ and MUAC were only found among the overweight urban children confirming that growth is accelerated in overweight and obese children. There were no visible clinical signs of malnutrition in the stunted children.

Conclusion

The present data seriously question the concept of stunting as prima facie evidence of malnutrition and chronic infection. 
141

142 
The clinical audience is wedded to the idea that stunting is nutritional. "There is convergence [also] among the nutrition community on the use of length-for-age as the indicator of choice in monitoring the long-term impact of chronic nutritional deficiency" [1]. The conventional definition of height stunting is, “...impaired growth and development that children experience from poor nutrition, repeated infection, and inadequate psychosocial stimulation" (WHO 2018). We accept that malnutrition can result in stunting but question the reverse equation, stunting = malnutrition. Stunting is frequent among children of low and middle-income countries (LMIC) [2]. But it is not specific for poverty, poor health and nutrition. Short stature when compared to modern references has been a frequent feature also among the healthy and wealthy European societies of the past. The pediatric journals of the late 19th and early 20th century reported that breastfed European infants and children, independent of social strata, grew far below WHO standards. Some $15-30 \%$ of adequately-fed historic European children would today be classified as stunted by the WHO standards [3]. Historic literature explicitly states that "...growth in height is largely independent of the extent and nature of the diet" [4]. Such statements are even more surprising when considering that the authors of these words were the pediatricians and school doctors of the starving German children raised during and after World War I. These pediatricians were not only aware of the physical effects of starvation on growth, they were also aware of the effects of nutrition interventions in starving children. Bloch and Abderhalden [5] described exceptional catch-up growth in height of 3-5 cm within 6-8 weeks during re-feeding. These outcomes significantly differ from the results of modern nutrition intervention studies in the LMIC [6]. Repeated infections and poor sanitation have also been claimed to be responsible for the shortness of stature in the LMIC. Yet, recent systematic reviews of water-sanitation-hygiene (WaSH), and educational interventions to prevent or treat stunting find little evidence for beneficial effects or effects so small as to fall within the measurement error of body length/height [7]. We feel that the failure of many of the modern interventions is not due to some general insensitivity to improvements in nutrition and living conditions, but it is due to a misconception of the interpretation of short stature. These articles provided a medical classification of malnutrition based on height-for-age that served as the basis for the modern understanding of the causes of short stature. The reasoning of these papers 
originated from observations and classification of Gomez et al. [11] who, when drawing up their classification, were assessing the prognosis of malnutrition according to the weight on admission to a hospital in Mexico City in the early 1950s. The significance of these observations was questioned later

177 [12], and even Seoane and Latham criticized a classification based on single parameters. Nevertheless, the basic strategy of associating nutrition and height remained and became entrenched in the literature by the publications of Waterlow who described a deficit in height-for-age due to undernutrition over a long period as, "...nutritional growth failure, but for the sake of brevity I shall call this condition stunting" [10]. This purely anthropometric definition of nutritional status was discussed in detail in a World Health Organization 1971 report [13] and was broadly accepted after publication of a Nestlé Nutrition Workshop in 1988 [14]. These papers have become the corner stones for the $21^{\text {st }}$ century diagnosis of undernutrition. The terms "stunting", "malnutrition", and "undernutrition" are used as synonyms in the epidemiological, medical and scientific literature. Prendergast \& Humphrey [15] summarized: "Linear growth failure is the most common form of undernutrition globally." We question this statement. undernutrition.

Starvation inhibits growth. This statement cannot be questioned, and there is ample evidence also in historic studies that this is the case. Keys and colleagues explicitly state that "there can be no doubt from the evidence in the literature that the growth of children can be and is influenced by a restriction in the food intake." [16, p. 1000-1001]. But reversing the line of argument by connecting short stature with shortage of food, lacks substantiation [17]. Scheffler et al. [18] re-analyzed cross-sectional growth studies of middle-class school children performed in Kolkata, India, and failed to detect an association 
2281. Stunted children are characterized by depleted fat stores, measurable by decreased triceps and 229 subscapular skinfold thickness [16,27].

2302. Better nutrition leads to less stunting.

231 1. Fat stores of less stunted children are less depleted, measurable by positive correlations between

232 height standard deviation scores (hSDS) and skinfold thickness.

233 2. Positive correlations between hSDS and the educational level of the parents assuming a priori that better parental education might minimize the risk of child malnutrition $[25,26]$.

2353. 3. Stunted children exhibit one or more visible clinical signs of malnutrition [27]. 
We question that "Linear growth failure is the most common form of undernutrition globally" [15], especially when stunting is prevalent in wealthy populations of LMICs. We present such data for |ndonesia.

\section{Subjects and methods}

We measured 1716 elementary school children, age between 6.0 and 13.2 years, from three Indonesian provinces in February and March 2018. Indonesia is not a poor country, it ranks $7^{\text {th }}$ out of 190 countries in the World Bank list of GDP [28], but Indonesian children are short in stature, and officially considered malnourished. $35.6 \%$ of Indonesian children were stunted in 2010 . The prevalence of stunting increased to $37.2 \%$ in 2013 [29]. With a global hunger index of 22, Indonesia is considered "seriously" affected by starvation [30]. This view, however, is strongly questioned by Indonesian pediatricians with direct clinical experience.

1. West-Timor, belonging to East Nusa Tenggara, is the poorest province of Indonesia with a nominal per capita GDP of US\$1,288 [31]. The population of this island is among the shortest of Indonesia [23], with an exceptionally high rate of stunted children. We measured in two representative elementary schools in urban Kupang/West-Timor , and one representative school in rural Soe/WestTimor. Kupang and Soe are situated $110 \mathrm{~km}$ apart from each other, connected by one asphalted road, driving time approximately three hours by private car. Kupang has some 330,000 inhabitants, a university, an airport and a harbor. Rural Soe has some 40,000 inhabitants, there is very little ecotourism and no remarkable industry. The population of West-Timor is comparably homogeneous. Except for refugees from nearby East-Timor, there was little migration in recent history. The people are very short, physical contact with modern tourists is virtually absent, but the pleasures of modern communication, such as television, internet and cellular phones are ubiquitously present in the young generation.

2. The "tourist island" Bali, is densely populated and economically more prosperous with a nominal per capita GDP of US\$3,791. Balinese people are the tallest Indonesians [23]. . We studied elementary school children of the city of Ubud. 
3. We studied elementary school children of rural North Sumatra, near Marbau that was selected because its nominal per capita GDP with $\$ 3,588$ is close to that of Bali, but the region is known for high stunting rates. Marbau has some 2500 inhabitants surrounded by rural settlements along the roads and is strongly involved in modern agro-industry. .

272

Parental informed consent was given. Ethical approval was provided by the Medical and Health Research Ethics Committee, Faculty of Medicine, Gadjah Mada University, Yogyakarta, Ref. nr. KE/FK/0175/EC/2018. We excluded one child with trisomy 21, one child with hydrocephalus, one child with club feet, and one child with gait disorder. Six children refused being measured.

277

All measurements were performed in the presence of the children's teachers, and supervised and accompanied by 26 local physicians, pediatricians, and medical residents. Birth date and information on parent education was obtained from school records. Parent education was expressed as the total number of school years of both parents including university education. We measured body height (technical error $2.5 \mathrm{~mm}$ ), weight (technical error $0.15 \mathrm{~kg}$ ), triceps (technical error $1.5 \mathrm{~mm}$ ), subscapular skinfolds (technical error $2.0 \mathrm{~mm}$ ), and clinical signs of malnutrition (hair, skin, and general appearance [13]). The children were lightly dressed and measured without shoes. Weight of the school uniforms was found to be close to $200 \mathrm{~g}$ in children below age 10 years, and about $300 \mathrm{~g}$ in children above age 10 years, and was subtracted from the weight measurements. Body height was determined by digital laser rangefinder GLM Professional ${ }^{\circledR}$ Bosch 250 VF [32] to the nearest millimeter, weight by digital scales (Soehnle, Nassau, Germany, Style Sense Compact 100) to the nearest 100g, and skinfold thickness by caliper (Holtain, Ltd. Crosswell, Crymych, UK) to the nearest 0.2 millimeter. All measurements were taken under standardized conditions [33]. The study included travelling of some $900 \mathrm{~km}$ by car, and extensive walking through residential areas surveying housing conditions, food markets, and sanitary facilities.

To estimate fatness, energy balance, and nutritional status we used the average of three measurements of triceps and three measurements of subscapular skinfold thickness ( $\bar{x} S F)$. Skinfold thickness changes with age and the distribution of fat depends on sex [37-39]. By averaging two 
skinfolds, we tried to avoid possible confounding due to age, sex, SES, and ethnic influences, and rather focused on the association between height, body fat and and external skeletal robusticity. Standard deviation scores for height (hSDS) and body mass index (BMI_SDS) were calculated according to WHO references [3]. To test whether particular effects only occurred in the very thin, or in the overweight/obese group of children, we focused on children with "normal BMI" (BMI_SDS<-1.28; and BMI_SDS $>1.28$ ). "Thinness" was defined as BMI below the $10^{\text {th }}$ centile, i.e. BMI_SDS $<-1.28$. The terms "overweight" and "obesity" were defined in the usual way with BMI_SDS>+1 or >+2, respectively.

To further estimate nutritional status and external skeletal robusticity, we measured mid-upper-arm circumferences (MUAC) and elbow breadth and calculated the frame index (FI, elbow breadth/height [34-36]). The latter has been used as a proxy for everyday physical activity levels [19].

\section{Statistical analysis}

We performed correlation analyses and linear mixed effects models with both fixed and random effects for hSDS, MUAC and $\bar{x} S F$, we then plotted the samples and fitted with LOWESS. LOWESS, also referred to as robust locally weighted regression, is a method for fitting a smooth line through $x-y$ data points [40]. Calculations were performed using SPSS version 25 (IBM SPSS Statistics, Armonk, NY), Statistica version 13.2., and with the programming language "R" (R-version 3.5.1 2018).

\section{Results}

Nutritional status as indicated by $\bar{x} S F$ and hSDS do not correlate (Figure 1).

Indonesian children lack relevant associations between $\bar{x}$ SF and hSDS (table 1). Rural boys of Soe were shortest (hSDS -2.08), and thinnest (BMI_SDS -1.41), closely followed by the girls (hSDS -1.90, BMI_SDS -1.25). $53 \%$ of the Soe boys, and $46 \%$ of the Soe girls were stunted. $\bar{x} S F$ (boys $5.50 \mathrm{~mm}$, girls $6.72 \mathrm{~mm}$ ) was significantly less than in the children of Kupang (boys $7.65 \mathrm{~mm}$, girls $8.75 \mathrm{~mm}$ ). Even though the very thin children of Kupang were slightly shorter, they were still significantly taller than the children of Soe. The correlation between $\bar{x} S F$ and $h S D S$ ranged from $r=0.12$ to $r=0.38$, 
explaining a maximum of $14.4 \%$ of the hSDS variance. The average number of parental school years was less in Soe (fathers 11.15 years, mothers 10.73 years) than in Kupang (fathers 13.33 years, mothers 13.05 years, $p<0.01)$. But the correlation between parental education and anthropometry was weak and only explain some $6.5 \%$ of the variance in hSDS and some $3.5 \%$ of the variance in $\bar{x} S F$.

To minimize the effects of overweight and thinness on growth, we eliminated the extremes and repeated the calculations with "nutritionally normal" children (BMI between +/- 1.28 BMI_SDS [3]). Doing so, the weak correlations between $\bar{x}$ SF and hSDS disappeared completely (table 1).

We also studied the thin children from West Timor, with $\bar{x} S F$ below the $10^{\text {th }}$ centile for mean subscapular and triceps skinfold thickness of German children [41]. 124 boys and 115 girls from Kupang, and 86 boys and 98 girls from Soe belonged to this sample. In these children, hSDS was slightly lower than the average hSDS of the respective groups of all West Timor children. Yet, the association between hSDS and $\bar{x} S F$ was insignificant. In the children of Kupang, the regression analysis showed insignificant betas of $-0.015(95 \% \mathrm{Cl}-0,246,0,207$; boys) and $0.048(95 \% \mathrm{Cl}-0.120$, 0.204 ; girls), and in the children of Soe, the regression analysis showed insignificant betas of -0.065 $(95 \% \mathrm{Cl}-0,190,0,351$; boys $)$ and $-0.136(95 \% \mathrm{Cl}-0.349,0.067$; girls $)$.

On the other side, many children from urban Ubud and rural Marbau were obese (table 1), though still shorter than the WHO reference (hSDS = -0.3). The correlation between hSDS and skinfold thickness was as weak, as in the urban children of Kupang $(r=0.354)$. In all samples the correlation between hSDS and $\bar{x}$ SF was negligible (Table 1).

Using linear mixed effects models with both fixed and random effects, we further studied the association between hSDS, MUAC and $\bar{x} S F$. When considering the whole sample, MUAC and $\bar{x} S F$ together explained $25.5 \%$ of the hSDS variance in boys, and $18.5 \%$ of the hSDS variance in girls. But the associations markedly decreased when considering the two parameters, and each population separately (Table 1). It is of particular interest that the shortest population, the children from rural Soe with stunting rates of $53.3 \%$ (boys) and $46.0 \%$ (girls), showed no meaningful association between hSDS, MUAC and $\bar{x} S F$. The hSDS variance explained by both parameters together, was $6.5 \%$ $(p=0.03)$ in boys, and $4.8 \%(p<0.01)$ in girls. The FI of the frequently stunted rural children of Soe, with $40.9(\mathrm{SD}=2.1) \mathrm{mm}$ (boys) and $39.0(\mathrm{SD}=1.8) \mathrm{mm}$ (girls) was highest among the various regions 
investigated. The FI of the frequently obese urban children of Ubud, however, was lowest with 38.6 $(\mathrm{SD}=2.8) \mathrm{mm}$ (boys) and $37.3(\mathrm{SD}=2.6) \mathrm{mm}$ (girls). Previous research reports that $\mathrm{Fl}$ is positively correlated with physical activity levels and uncorrelated with body fatness [42. On this basis the high level of physical activity of the Soe children rather contracts the vision that the short stature of these children results from malnutrition or infection.

It is of interest to note that the associations between hSDS and both skinfold thickness and MUAC were least in the stunted rural children of Soe, and greatest in the urban overweight children of Ubud.

We found no visible clinical signs of PEM such as edema, irritability, apathy, or decreased social responsiveness, and anxiety, nor glossitis and nail changes (iron deficiency), goiter (iodine deficiency), hair changes (vitamin A deficiency), nor signs of diminished immune response such as multiple skin infections and poor wound healing [27]. We rather met happy, vivid, and very interested children in apparently good health. We incidentally found an almost $100 \%$ prevalence of untreated dental caries, indicating very poor dental hygiene in the rural children of Soe and Marbau. A systematic review of longitudinal studies reported that, "Evidence of the association between anthropometric measurements and dental caries is conflicting and remains inconclusive" [43]. Less than one percent of the children wore eyeglasses indicating underdiagnosed visual impairments.

\section{Discussion}

The present analysis rejects the three hypotheses proposed here, all of which are based on the conventional definition of height stunting as due primarily to nutritional inadequacy: (1) stunted children are not uniformly characterized by depleted fat stores; (2) fat stores of less stunted children are not less depleted and better parental education does not minimize the risk of child undernutrition; (3) stunted children do not exhibit visible clinical signs of PEM. Quite in contrast to common expectations, the associations between growth and parameters reflecting nutritional status such as skinfold thickness, $\mathrm{FI}$, and MUAC were least in the stunted rural children of Soe, and greatest in the urban overweight children of Ubud. Small subcutaneous fat depots and narrow upper arm circumferences do not appear to inhibit growth. The data rather confirm that growth is accelerated in 
overweight and obese children. The investigation in 1716 Indonesian school children with stunting rates up to $53 \%$ in rural Soe, thus, does not support the modern concept of stunting as an indicator of malnutrition.

Arguments have been raised that observing signs of adequate or even overnutrtion in stunted school age children does not exclude undernutrition at younger age, as stature is the summary of all previous height increments. Such arguments are compelling at first view. But growth is plastic. Long periods of childhood starvation are usually followed by catch-up growth [44] and complete recovery. This has repeatedly been shown in school children born during and shortly after wars $[45,46]$. The effect of refeeding was particularly well documented in historic studies of severely undernourished children raised during World War I $[47,48]$ with average catch-up growth rates of 3-5 cm within eight weeks of refeeding. We found no evidence in the historic European pediatric literature that supports the view that intermittent infant undernutrition due to war and post-war food shortages result in permanent height deficits.

Thus, we cannot share the opinion expressed in the quotation in our Introduction that length-for-age is the indicator of choice to monitor chronic nutritional deficiency [1]. We appreciate that this is the working agenda of public health specialists, governments, the food industry and funding bodies. In recent communication with the German Federal Ministry for Economic Cooperation and Development (Bundesministerium für wirtschaftliche Zusammenarbeit und Entwicklung) we were told that this Ministry, “...follows the international definition that stunting results from chronic malnutrition - so-called "hidden hunger". Affected people often receive a sufficient (energy-rich) but not a balanced diet" (email communication to $\mathrm{MH}, 09$ May 2018). The belief that height growth depends on an ideal intake of food and essential nutrients is intuitive. But intuition may not necessarily be true [49]. We are aware that the estimates of the global prevalence of stunting for under 5-year-olds is close to 155 million [50]. We do not question that these children are short in stature, but we question that all these children are undernourished [51]. Nearly 100 years ago, after World War I, the German pediatrician and school physician Schlesinger summarized that "the child's longitudinal growth is largely independent of the extent and nature of the diet ...". Very similar data were published by other paediatricians $[4,5]$. 
Our new Indonesian study consisted of extensive ethnographic observations of residential areas and was supervised and accompanied by 26 local physicians, pediatricians, and medical residents, with direct clinical experience of urban and rural communities. All of us failed to detect visible clinical signs of PEM and essential nutrient deficiencies. Instead we detected obesity except for Soe children. A positive energy balance has mild stimulatory effects on developmental tempo and growth [25], but the obese children were not the tall children. Quite in contrast, even the obese populations were shorter in height than WHO references. In Guatemala it has been known since the 1990s that the high prevalence of stunting is caused by factors other than nutrient intake [52]. A survey of eight rural, Maya villages and an urban medical clinic in Quetzaltenango, Guatemala with a high percentage of Maya patients found that for 306 newborns, with a median age of 19 days postpartum, $38 \%$ were 'stunted' at birth and that maternal height explained only $3 \%$ of the variability in hSDS of the newborns [53]. The nutrient intake of the mothers may have been inadequate but as we discussed above, systematic reviews of numerous nutrient supplementation interventions in Guatemala and elsewhere find little or no positive impact on newborn length. The same research team published a more recent report based on their participatory action research conducted within a socioecological framework [54]. The study enrolled a longitudinal cohort of 155 women, followed during pregnancy (6-9 months), early (0-6 weeks), and later (4-6 months) postpartum, and 2 cross-sectional cohorts (60 early and 56 later postpartum). The authors report that diet diversity and adult food security (38\%) were low. Urinary and gastrointestinal infections were rare $(<5 \%)$ but reports of distress in meaningful Maya social categories was frequent $(20 \%-50 \%)$. "Participants reported low maternal autonomy (81\%), high paternal support (70\%), small social support networks (2.7 +/- 1.3 individuals), and high trust in family (88\%) and community-based institutions (61\%-65\%) but low trust in government services (6\%). Domestic violence was commonly reported (22\%). Infant stunting was common (36\% early postpartum and $43 \%$ later postpartum) despite frequent antenatal care visits $(7.5+3.8)$. Participant engagement with the research team did not influence study outcomes based on comparisons between longitudinal and cross-sectional cohorts" (p. 415). These findings confirm the earlier study of high stunting prevalence at birth and associates this with maternal psychosocial distress and insecurity more than diet or infection.

Education matters $[23,24]$. Social strata and education are associated with child growth. The 
But again, the within-group correlations were weak. Within each group, parental education failed to suggest major impact of education on height. We found no satisfying educational explanation for the one standard deviation height difference between rural Soe and urban Kupang.

Heredity has been an argument for short stature. West-Timor, a far-off region with little migration from outside and almost no physical contact with modern Europeans, might serve as an example of genetic isolation, but it fails to explain the difference of one SD between height of children raised only $110 \mathrm{~km}$ apart from each other. Similar considerations apply for Maya children from Guatemala born in the United States. They are, on average, $11 \mathrm{~cm}$ taller than their siblings born and raised in Guatemala [55]. The genetic argument is further weakened when considering recent Genome-Wide Association Studies stating that genetic loci associated with height only explain some $12.3 \%$ of the total variance in adult human height [56].

Why are these children so short?

This question is difficult, as it might imply a negative connotation of being short. We rather suggest asking why are these children not as tall as modern European children? Modern Indonesians are slightly taller than wealthy Europeans some 150 years ago. Kotelmann studied upper class adolescent boys from an elite humanistic school in Hamburg [57]. These boys were delayed in pubertal development by almost two years and reached an average near final height around $165 \mathrm{~cm}$. Similar patterns of growth delay and short height were reported from aristocratic and working-class boys educated at Carlsschule, Stuttgart, an $18^{\text {th }}$ century boarding school [58].

Recent evidence suggests community effects on height [59]. Among social mammals, strategic growth adjustments have been described [60], mechanisms that may also apply for the regulation of human growth [61].

We propose that living in poverty with food and housing insecurity, emotional trauma, and other stress insults are some, but not all of the factors that explain the comparably short stature of those many modern nations listed by the NCD Risk Factor Collaboration [62]. 
In addition, we propose that children can be short because they lack those social, economic, political and psychological infrastructures that in the modern Western world have stimulated growth beyond all previously recorded limits for height [62]. Good nutrition, health, general living conditions and caregiving are essential prerequisites for growth, but they do not in themselves, maximize stature. We emphasize the bilateral link between height and social position [63]. Taller stature is associated with higher socioeconomic status [64], but also social position and political environment modulate growth $[59,65]$, a vision that opens new fields of biosocial research. Here, the classical verdict of Liberté, Égalité, Fraternité, becomes more than just a revolutionary statement. Groups who feel liberty, who practice social equality and peaceful coexistence - the Northern European countries may serve as political examples - are known to be tall.

There are limits to this study. The underlying mechanisms of social-emotional growth adjustments are still unclear. The present investigation lacks detailed information on daily food intake and the composition of the diet, and confirmative laboratory data on serum iron, zinc, thyroid hormones, vitamin D levels, etc.

This work does not question the obvious causal association of energy insufficiency, essential nutrient and chronic infection with reduced linear growth. We are not advocating the discredited idea that the short stature of children and adults living in poverty may be a genetic adaptation or beneficial homeostatic response acquired from generations of malnutrition and is without any pathological consequence.

But we do question the inappropriate use of global growth standards to conclude that stunting is prima facie evidence of malnutrition and chronic infection. We question that government ministries and nongovernmental organizations base their raison d'être on the term "stunting" as a synonym for "chronic malnutrition". We intend to stimulate the debate about the inappropriate misapplication of a global growth reference derived from high SES and mostly westernized populations when applied to apparently healthy and well-nourished low SES children raised in remote areas of former European colonies. We propose a more precise identification of growth inhibition caused by malnutrition based on a combination of measurements, including height, triceps and subscapular skinfolds, and other indicators of energy balance and nutrient adequacy. 
513

We protest against the misinterpretation of short stature as a proxy indicator for malnutrition.

Malnutrition leads to stunting, but stunting by itself does not indicate malnutrition.

\section{Acknowledgements}

We gratefully acknowledge significant support by the local authorities, and in particular, by Octavianus NE, Jelalu ES, Lubis M, Arto KS, Siregar C, Rahayu S, Nasution A, Andreas ST, Harahap MA, Sihotang RD, Winny, Suryawan WB, Prayoga AW, Satria E, Paramita ADP, Febriyanti KD, Mahaputri AS, Dhyna AD, Pratama GA, Trisnia A, Purnama IA, Wisudarma GA, from the Medical Faculty Nusa Cendana University, Kupang-East Nusa Tenggara, Indonesia;, from the School of Medicine, University of Sumatera Utara, Medan, Sumatera Utara, Indonesia; and from Regional General Hospital Wangaya Denpasar.

\section{Disclosure statement:}

The authors have nothing to disclose

\section{References}

1. Lartey A. What would it take to prevent stunted growth in children in sub-Saharan Africa? Proc Nutr Soc. $2015 ; 74: 449-53$.

\section{Black RE, Victora CG, Walker SP, Bhutta ZA, Christian P, de Onis M, Ezzati M, Grantham-} McGregor S, Katz J, Martorell R, Uauy R; Maternal and Child Nutrition Study Group. Maternal and child undernutrition and overweight in low-income and middle-income countries. Lancet. 2013 Aug 3;382(9890):427-451. doi: 10.1016/S0140-6736(13)60937-X

\section{3. https://www.who.int/growthref/en/}


543 4. Hermanussen M, Bogin B, Scheffler C. Stunting, starvation and refeeding: a review of forgotten

544 19th and early 20th century literature. Acta Paediatr. 2018 Jul;107(7):1166-1176. doi:

545 10.1111/apa.14311.

546

547 5. Hermanussen M, Bilogub M, Lindl AC, Harper D, Mansukoski L, Scheffler C. Weight and height

548 growth of malnourished school-age children during re-feeding. Three historic studies published shortly

549 after World War I. Eur J Clin Nutr. 2018 Aug 30. doi: 10.1038/s41430-018-0274-z. [Epub ahead of

550 print].

551

552 6. Goudet S, Griffiths P, Bogin B, Madise N. Interventions to tackle malnutrition and its risk factors in

553 children living in slums: a scoping review. Ann Hum Biol. 2017 Feb;44(1):1-10. doi:

$554 \quad 10.1080 / 03014460.2016 .1205660$.

555

556 7. Dangour AD, Watson L, Cumming O, Boisson S, Che $\mathrm{Y}$, Velleman $\mathrm{Y}$, et al. Interventions to improve 557 water quality and supply, sanitation and hygiene practices, and their effects on the nutritional status of 558 children. Cochrane Database Syst Rev. 2013 Aug 1;(8):CD009382. doi:

559 10.1002/14651858.CD009382.pub2.

560

561 8. Seoane N, Latham MC. Nutritional anthropometry in the identification of malnutrition in childhood. J

562 Trop Pediatr Environ Child Health 1971; 17: 98-104.

563

564

9. Waterlow JC. Classification and definition of protein-calorie malnutrition. Br Med J 1972; 2: 566-9.

565

566

10. Waterlow JC. Note on the assessment and classification of protein-energy malnutrition in children.

567 Lancet. 1973 Jul 14;2(7820):87-9.

568

569 11. Gomez F, Galvan RR, Frenk S, Munoz JC, Chavez R, Vazquez J. Mortality in second and third 570 degree malnutrition. J Trop Pediatr (Lond). 1956 Sep;2(2):77-83.

571 

Organ. 1980;58(5):773-7.

574

575 13. Joint FAO/WHO. Expert Committee on Nutrition. World Health Organization Technical Report 576 Series, No. 477. Geneva:WHO, 1971.

577

14. Waterlow JC, editor. Linear growth retardation in less developed countries. Nestle Nutrition Workshop Series, 1988, Vol. 14. New York: Nestec Ltd, 1988.

580

15. Prendergast AJ, Humphrey JH. The stunting syndrome in developing countries. Paediatr Int Child Health 2014; 34: 250-65.

583

16. Keys A, Brozek J, Henschel A, Mickelsen O, Longstreet Taylor H. The biology of human starvation. The University of Minnesota Press. Minneapolis. 1950.

17. Hermanussen M, Wit JM. How Much Nutrition for How Much Growth? Horm Res Paediatr. 2017;88(1):38-45.

589

18. Scheffler C, Krützfeldt LM, Dasgupta P, Hermanussen M. No association between fat tissue and height in 5019 children and adolescents, measured between 1982 and in 2011 in Kolkata/India. Anthropol Anz. 2018 Jun 11;74(5):403-411.

593 income countries. Anthropol Anz. 2019 in print supplementation for improving the physical and psychosocial health of socio-economically disadvantaged children aged three months to five years. - Cochrane Database 2015 Syst Rev: CD009924. doi: 10.1002/14651858.CD009924.pub2.

601 
602

603

604

605

606

607

608

609

610

611

612

613

614

615

616

617

618

619

620

621

622

623

624

625

626

627

628

629

630

631

632

21. Goudet S, Griffiths P, Bogin B, Madise N. Interventions to tackle malnutrition and its risk factors in children living in slums: a scoping review. Ann Hum Biol. 2017 Feb;44(1):1-10. doi:

10.1080/03014460.2016.1205660.

22. Grantham-McGregor SM, Fernald LC, Kagawa RM, Walker S. Effects of integrated child development and nutrition interventions on child development and nutritional status. Ann N Y Acad Sci. 2014 Jan;1308:11-32. doi: 10.1111/nyas.12284.

23. Pulungan AB, Julia M, Batubara JRL, Hermanussen M. Indonesian National Synthetic Growth Charts. Acta Scientific Paediatrics 2018: 1;20-34.

24. Rietsch K, Eccard J, Scheffler C. 2013. Decreased External Skeletal Robustness Due to Reduced Physical Activity? Am J Hum Biol25:404-410. DOI:10.1002/ajhb.22389

25. Vollmer S, Bommer C, Krishna A, Harttgen K, Subramanian SV. The association of parental education with childhood undernutrition in low- and middle-income countries: comparing the role of paternal and maternal education. Int J Epidemiol. 2017 Feb 1;46(1):312-323. doi: 10.1093/ije/dyw133.

26. Imdad A, Yakoob MY, Bhutta ZA. Impact of maternal education about complementary feeding and provision of complementary foods on child growth in developing countries. BMC Public Health. 2011 Apr 13;11 Suppl 3:S25. doi:10.1186/1471-2458-11-S3-S25.

27. Behrman RE, Kliegman RM, Jenson HB (1999) Nelson, Textbook of Pediatrics. $16^{\text {th }}$ ed. Saunders. Philadelphia, London, Toronto.

28. https://en.wikipedia.org/wiki/List_of_countries_by_GDP_(PPP).

29. Badan Penelitian dan Pengembangan Kesehatan Kementerian Kesehatan RI. Riset Kesehatan

Dasar 2013. Jakarta: 2013. p.4.

30. http://www.globalhungerindex.org/pdf/en/2017/posters.pdf. 
31. https://en.wikipedia.org/wiki/List_of_Indonesian_provinces_by_GRP_per_capita.

32. Schrade L, Scheffler C. Assessing the applicability of the digital laser rangefinder GLM Professional Bosch 250 VF for anthropometric field studies. Anthropol Anz. 2013;70(2):137-45.

33. Knussmann R. Anthropologie, Handbuch der vergleichenden Biologie des Menschen. Fischer, Stuttgart, 1988.

34. Frisancho AR, Garn SM. Skin-fold thickness and muscle size: implications for developmental status and nutritional evaluation of children from Honduras. The American journal of clinical nutrition. 1971 May 1;24(5):541-6.

35. Friedman JF, Phillips-Howard PA, Mirel LB, Terlouw DJ, Okello N, Vulule JM, Hawley WA, Nahlen $\mathrm{BL}$, ter Kuile F. Progression of stunting and its predictors among school-aged children in western Kenya. European journal of clinical nutrition. 2005 Aug;59(8):914.

36. Frisancho AR. Triceps skin fold and upper arm muscle size norms for assessment of nutritional status. The American journal of clinical nutrition. 1974 Oct 1;27(10):1052-8.

37. Maynard LM, Wisemandle W, Roche AF, Chumlea WC, Guo SS, Siervogel RM. Childhood body composition in relation to body mass index. Pediatrics. 2001 Feb;107(2):344-50.

38. Wells JC 2007: Sexual dimorphism of body composition.-Best Pract Res Clin Endocrinol Metab. 21(3):415-30.

39. Scheffler C, Obermüller J. Development of fat distribution patterns in children and its association with the type of body shape assessed by the Metric-Index. Anthropol Anz. 2012;69(1):45-55.

40. Cleveland WS. Robust Locally Weighted Regression and Smoothing Scatterplots. J Am Stat Assoc. 1979;74: 829-836. 
664

665

666

667

668

669

670

671

672

673

674

675

676

677

678

679

680

681

682

683

684

685

686

687

688

689

690

691
41. Schilitz A. Körperliche Entwicklung und Körperzusammensetzung von Brandenburger

Schulkindern im Geschlechter- und Altersgruppenvergleich (Berichte aus der Biologie). Shaker,

Maastricht und Herzogenrath. 2001.

42. Frisancho R. Anthropometric Standards for the Assessment of Growth and Nutritional Status.

University of Michigan Press, 1990.

43. Li LW, Wong HM, Peng SM, McGrath CP. Anthropometric measurements and dental caries in children: a systematic review of longitudinal studies. Adv Nutr. 2015 Jan 15;6(1):52-63. doi: 10.3945/an.114.006395.

44. Boersma B (1998) Catch-up growth in children. Leiden: Thesis.

45. Brundtland GH (1980) Height, weight and menarcheal age of Oslo schoolchildren during the last 60 years. Ann Hum Biol 7:307-322.

46. Hagen W. Zum Akzelerationsproblem Deutsche Medizinische Wochenschrift 1961;86:220-223.

47. Hermanussen M, Bogin B, Scheffler C. Stunting, starvation and refeeding: a review of forgotten 19th and early 20th century literature. Acta Paediatr. 2018 Jul;107(7):1166-1176.

48. Hermanussen M, Bilogub M, Lindl AC, Harper D, Mansukoski L, Scheffler C. Weight and height growth of malnourished school-age children during re-feeding. Three historic studies published shortly after World War I. Eur J Clin Nutr. 2018 Dec;72(12):1603-1619.

49. Hermanussen M, Scheffler C, Groth D, Bogin B. Editorial. Perceiving stunting - Student research and the "Lieschen Müller effect" in nutrition science. Anthropol Anz. 2018 Jun 11;74(5):355-358. 
692

693

694

695

696

697

698

699

700

701

702

703

704

705

706

707

708

709

710

711

712

713

714

715

716

717

718

719

720

721

722

50. de Onis M, Branca F. Childhood stunting: a global perspective. Matern Child Nutr 2016; 12 Suppl 1: $12-26$.

51. Hermanussen M, Wit JM. How Much Nutrition for How Much Growth? . Horm Res Paediatr. 2017;88(1):38-45. doi: 10.1159/000454832.

52. Solomons NW, Mazariegos M, Brown KH, Klasing K. The underprivileged, developing country child: environmental contamination and growth failure revisited. Nutr Rev. 1993 Nov;51(11):327-32.

53. Solomons NW, Vossenaar M, Chomat AM, Doak CM, Koski KG, Scott ME. Stunting at birth: recognition of early-life linear growth failure in the western highlands of Guatemala. Public Health Nutr. 2015 Jul;18(10):1737-45. doi: 10.1017/S136898001400264X

54. Chomat AM, Solomons NW, Koski KG, Wren HM, Vossenaar M, Scott ME. Quantitative methodologies reveal a diversity of nutrition, infection/illness, and psychosocial stressors during pregnancy and lactation in rural Mam-Mayan mother-infant dyads from the Western Highlands of Guatemala, Food and Nutrition Bulletin 2015; 36(4): 415-440.

55. Bogin B, Smith P, Orden AB, Varela Silva MI, Loucky J. Rapid change in height and body proportions of Maya American children. Am J Hum Biol. 2002 Nov-Dec;14(6):753-61.

56. Tyrrell J, Jones SE, Beaumont R, Astley CM, Lovell R, Yaghootkar H et al. Height, body mass index, and socioeconomic status: mendelian randomisation study in UK Biobank. BMJ 2016;352:i582.

57. Kotelmann, L. (1879) Die Körperverhältnisse der Gelehrtenschüler des Johanneums in Hamburg:

Ein statistischer Beitrag zur Schulhygiene. Zeitschrift des Königlichen Preussischen statistischen Bureau's. Berlin. Nachdruck.

58. Hartmann W. Beobachtungen zur Akzeleration des Längenwachstums in der zweiten Hälfte des 18. Jahrhunderts. „Carlsschule“. Dissertation. Frankfurt. 1970. 
59. Hermanussen M, Alt C, Staub K, Aßmann C, Groth D. The impact of physical connectedness on body height in Swiss conscripts. Anthropol Anz. 2014;71(4):313-27.

60. Huchard E, English S, Bell MB, Thavarajah N, Clutton-Brock T. Competitive growth in a cooperative mammal. Nature. 2016 May 26;533(7604):532-4.

61. Hermanussen M, Scheffler C. Stature signals status: The association of stature, status and perceived dominance - a thought experiment. Anthropol Anz. 2016 Nov 1;73(4):265-274.

62. NCD Risk Factor Collaboration (NCD-RisC). A century of trends in adult human height. eLife, 2016, 5, e13410. Available at: http://www.ncbi.nlm.nih.gov/pubmed/27458798.

63. Hermanussen M. Stunted growth. Eur J Clin Nutr. 2016 Jun;70(6):647-9.

64. Bogin B, Scheffler C, Hermanussen M. Global effects of income and income inequality on adult height and sexual dimorphism in height. Am J Hum Biol. 2017;e22980. https://doi.org/10.1002/ajhb.22980.

65. Bogin B, Hermanussen M, Scheffler C. As tall as my peers - similarity in body height between migrants and hosts. Anthropol. Anz. 2018; 74/5 Supplement 1: 363-374. 
$747 \quad$ Legend to figure 1:

748

749 hSDS and mean skinfold thickness [(subscapular + triceps)/2] of 206 children from urban

750 Kupang/West-Timor, Indonesia, 107 children from rural Soe/West-Timor, Indonesia, and 591 children

751 from urban Ubud/Bali, Indonesia. Age and sex averaged centiles (p3, p50, and p97) of mean

752 subscapular and triceps skinfold thickness of German children [41] (bars) are added for comparison.

753 hSDS and $\bar{x}$ SF were plotted and fitted with LOWESS to better highlight the overall shape of the

754 relationship between the $x$ and $y$ variables. Please note that the scale of the Ubud children differs due

755 to the exuberant prevalence of obesity.

756

757 
Table 1 Anthropometric data and parental education of 908 boys and 808 girls from elementary schools in Ubud (Bali), Kupang (two schools, West-Timor), Soe (West-Timor), and Marbau (two schools, North Sumatra). SD scores were obtained using WHO references [3].

Ubud

boys (6-13 years old)
$\mathrm{n}$
$\mathrm{n}$ - normal body mass (BMI_SDS +/-
$1.28)$
$\%$ - BMI between SDS +/-1.28
$\%$ - hSDS <-2 (\% stunted)
$\%$ - BMI_SDS < - 1.28 (\% thinness)
$\%$ - BMI_SDS > 1 (\% overweight)
$\%$ - BMI_SDS > 2 (\% obese)
mean hSDS
SD for hSDS
mean BMI_SDS
SD for BMI_SDS
mean skinfold (SF [mm])
SD for skinfold [mm]
MUAC [cm]
SD for MUAC [cm]
Frame index
SD for Frame index

coeff corr SF * hSDS

coeff corr SF * hSDS (BMI_SDS +/- 1.28)

coeff corr MUAC * hSDS
317

186

58.7

5.4

9.2

35.6

21.4

$-0.34$

1.00

0.54

1.61

12.01

7.86

21.4

2.1

38.6

2.8

0.38

0.20

0.51
Kupang

Soe

Marbau

278

196

$93 \quad 46$

45.2

43.0

70.5

21.8

53.3

25.2

40.8

55.1

19.8

15.0

1.9

11.5

11.6

0.0

4.7

$-1.10$

$-2.08$

$-1.33$

1.00

0.93

0.99

$-0.69$

$-1.41$

$-0.37$

1.78

1.06

1.19

7.65

5.50

8.67

4.66

1.50

4.60

18.4

16.6

20.4

1.9

1.3

1.7

39.0

40.9

39.8

2.4

2.1

1.8

0.38

0.12

0.32

0.12

0.09

0.13

0.35

0.25

0.43

\begin{tabular}{lcccc} 
girls (6-13 years old) & & & & \\
$\mathrm{N}$ & 274 & 197 & 113 & 224 \\
$\mathrm{n}$ - normal body mass (BMI_SDS +/- & 182 & 106 & 53 & 156 \\
$\begin{array}{l}1.28) \\
\% \text { - BMI between SDS +/-1.28 }\end{array}$ & 66.4 & 53.8 & 46.9 & 69.6 \\
$\%$ - hSDS < -2 (\% stunted) & 4.0 & 17.8 & 46.0 & 23.7 \\
$\%$ - BMI_SDS < - 1.28 (\% thinness) & 8.8 & 34.0 & 53.3 & 18.4 \\
\hline
\end{tabular}




\begin{tabular}{lcccc}
\hline \% - BMI_SDS > 1 (\% overweight) & 29.2 & 13.7 & 4.4 & 8.9 \\
\% - BMI_SDS > 2 (\% obese) & 12.4 & 5.1 & 0.0 & 3.6 \\
mean hSDS & -0.27 & -1.00 & -1.90 & -1.27 \\
SD for hSDS & 0.97 & 1.02 & 1.11 & 0.94 \\
mean BMI_SDS & 0.30 & -0.65 & -1.25 & -0.41 \\
SD for BMI_SDS & 1.26 & 1.49 & 1.01 & 1.10 \\
mean skinfold (SF [mm]) & 12.33 & 8.75 & 6.72 & 10.34 \\
SD for skinfold [mm] & 5.40 & 4.06 & 2.15 & 4.31 \\
MUAC [cm] & 20.9 & 18.4 & 17.0 & 20.0 \\
SD for MUAC [cm] & 1.8 & 1.7 & 1,4 & 1,7 \\
Frame index & 37.3 & 37.4 & 39.0 & 38.2 \\
SD for Frame index & 2.6 & 2.3 & 1.8 & 1.7 \\
& & & & \\
coeff corr SF * hSDS & 0.33 & 0.24 & 0.21 & 0.12 \\
coeff corr SF * hSDS (BMI_SDS +/- 1.28) & 0.27 & 0.07 & 0.13 & -0.04 \\
coeff corr MUAC * hSDS & 0.37 & 0.35 & 0.19 & 0.34
\end{tabular}

$\begin{array}{lcccc}\text { parental education - both sexes } & & & & \\ \text { paternal education (years) } & 12.28 & 13.33 & 11.15 & 9.18 \\ \text { maternal education (years) } & 12.40 & 13.05 & 10.73 & 8.62 \\ & & & & \\ \text { coeff corr hSDS * paternal education } & 0.04 & 0.13 & 0.04 & 0.12 \\ \text { coeff corr SF * paternal education } & 0.00 & 0.15 & 0.10 & 0.10 \\ \text { coeff corr hSDS * maternal education } & 0.04 & 0.09 & 0.06 & 0.13 \\ \text { coeff corr SF * maternal education } & -0.07 & 0.06 & 0.16 & 0.10\end{array}$




\section{Height SDS versus mean skinfold [ (subscapular + triceps)/2 ]}

\section{Indonesia}
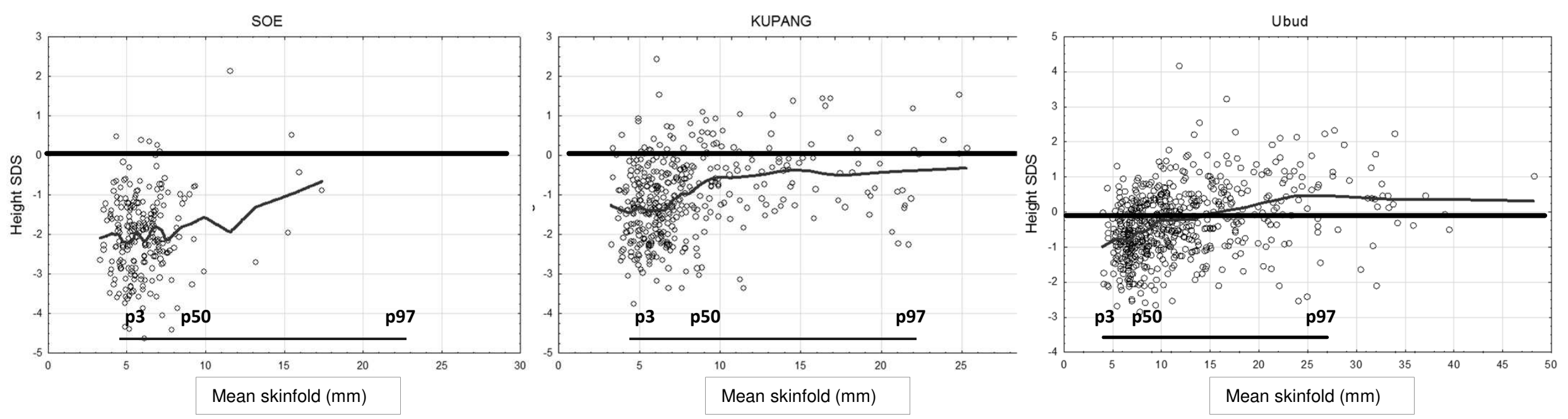